\title{
Impact of Veneer Layouts on Plywood Tensile Strength
}

\section{Utjecaj položaja furnira u strukturi furnirskih ploča na njihovu vlačnu čvrstoću}

\author{
Preliminary paper • Prethodno priopćenje \\ Received-prispjelo: 11. 7. 2016. \\ Accepted-prihvaćeno: 11. 5. 2017. \\ UDK: $630 * 832.281 .2 ; 630 * 832.282 .7$ \\ doi:10.5552/drind.2017.1634
}

\begin{abstract}
The aim of the research presented in this paper is to study the plywood tensile strength through a change of the position of layers in the panel structure around the central axis, without changing the number and thickness of veneers. So far, it has been known that the veneer layout in plywood structure has a significant impact on plywood bending properties. Besides these mechanical properties, the tensile strength of plywood is also a property that can define the use of plywood as a structural or non-structural panel.

For studying the impact of veneer layout on plywpood tensile strength, experimental models of nine-layer plywood were made. The models were made from peeled beech veneer with the thickness of 1.2, 1.5, 2.2 and 3.2 mm. The modelling was performed on the basis of changing the position of veneer, $3.2 \mathrm{~mm}$ thick, around the central axis. Pure water-soluble phenol-formaldehyde resin was used as plywood binder.

The tensile strength of plywood panels was tested in five directions: parallel and perpendicular to the face grain, as well as at the angle of $22.5^{\circ}, 45^{\circ}$ and $67.5^{\circ}$ to the face grain of the plywood panel. On the basis of the obtained data for tensile strength in different directions of plywood panel, the coefficient of equality of tensile strength of plywood models was calculated $\left(K_{e t}\right)$. The coefficient of mass quality $\left(K_{m q}\right)$ was calculated, too.

The research results showed that different veneer layouts in plywood structure have a significant impact on plyood tensile strength. All tested plywood models meet the defined values of tensile strength in accordance with the requirements of the national (MKC) standard for structural plywood for use in construction. Different layouts of veneer sheets in panel structure give opportunities for production of panels with different strength characteristics.
\end{abstract}

Key words: plywood, veneers, tensile strength, changes, position, layers

SAŽETAK・U radu su opisana istraživanja čiji je cilj bio proučiti vlačnu čvrstoću furnirskih ploča s obzirom na promjenu položaja furnira u strukturi ploče oko središnje osi, bez promjene broja i debljine furnira. Do danas je poznato da položaj furnira u strukturi furnirskih ploča ima znatan utjecaj na savojna svojstva furnirskih ploča. Osim savojnih svojstava furnirskih ploča, važna je i njihova vlačna čvrstoća, koja može utjecati na to hoće li furnirske ploče biti primijenjene kao strukturni ili kao nestrukturni element. Za proučavanje utjecaja položaja furnira na vlačnu čvrstoću furnirske ploče izrađeni su eksperimentalni modeli devetoslojnih furnirskih ploča. Modeli su napravljeni od bukovih ljuštenih furnira debljine 1,2; 1,5; 2,2 i 3,2 mm. Modeliranje je obavljeno na temelju promjene položaja furnira debljine 3,2 mm oko središnje osi. Kao vezivo je upotrijebljena čista vodotopljiva fenol-formaldehidna smola. Vlačna čvrstoća furnirskih ploča ispitana je u pet smjerova: paralelno i okomito na smjer vlakanaca vanjskih furnira te pod kutom od $22,5^{\circ}, 45^{\circ} i 67,5^{\circ} \mathrm{s}$ obzirom na smjer vlakanaca vanjskih furnira

\footnotetext{
${ }^{1}$ Authors are assistant professor and professors at the University of SS. Cyril and Methodius in Skopje, Faculty of Design and Technologies of Furniture and Interior, Skopje, Republic of Macedonia

Autori su docentica i profesori Sveučilišta Sv. Ćiril i Metodij u Skoplju, Fakultet dizajna i tehnologije namještaja i enterijera, Skoplje, Republika Makedonija.
} 
ploče. Na temelju dobivenih podataka o vlačnoj čvrstoći u različitim smjerovima ploče, izračunan je koeficijent jednakosti vlačne čvrstoće modela furnirskih ploča $\left(K_{e}\right)$. Također je izračunan i koeficijent masene kvalitete $\left(K_{m q}\right)$. Rezultati istraživanja pokazali su da različit položaj furnira u strukturi furnirskih ploča znatno utječe na njihovu vlačnu čvrstoću. Svi ispitani modeli furniskih ploča zadovoljavaju vrijednosti vlačne čvrstoće definirane u skladu s makedonskim normama za strukturne furnirske ploče namijenjene uporabi u graditeljstvu. Različit položaj furnira u strukturi ploče omogućuje proizvodnju ploča različitih svojstava čvrstoće.

Ključne riječi: furnirske ploče, furniri, vlačna čvrstoća, promjena položaja furnira

\section{INTRODUCTION}

\section{UVOD}

The wide range of wood-based composites includes materials for structural or non-structural use for indoor and outdoor application (Youngquist, 1999). Plywood is one of the major types of wood-based composite materials for structural use. It represents a flat panel made of odd number of layers made of veneer sheets, where the grain direction of the adjacent layers is at right angles.

The cross-laminated layup of veneer layers gives plywood excellent strength characteristics, stiffness and dimensional stability (Youngquist, 1999). Plywood is used in a variety of structural applications, such as flooring, siding, roofing, shear walls, formwork and engineered wood products (prefabricated I-joists, box beams, stressed-skin panels and panelized roofs) (Stark et al., 2010).

Plywood properties depend on the quality of the veneer, wood species, number and order of layers, as well as of the adhesive used for plywood bonding (Youngquist, 1999; Hráskỳ and Král, 2005; Stark et al., 2010; Bal and Bektaş, 2014).

Dimensional uniformity and reliable, consistent structural properties make plywood an attractive choice of material from both a design and construction perspective. Because of its lightness, directional strength properties and inherent stiffness, plywood is an excellent material for fixing beam elements to timber so as to produce a composite construction (EWPAA, 2009).

The performance of wood composite materials is characterized by a wide range of engineering properties. The proper use of plywood requires a bigger understanding of mechanical properties of this material (Cai and Ross, 2010). These properties are some of the most important characteristics of plywood that are commonly considered (Kljak and Brezovic, 2007). Thensile strength of plywood is also an important property that shoud be taken into consideration when selecting materials for construction purposes.

The tensile strength of plywood is of a particular importance in stress-skin panels and sandwich-type structures, where plywood facings are the load-bearing members (ASTM Technical publication No. 194).

In order to produce stable panels that can meet the modern exploitation requirements, plywood is constantly subjected to research. Improving of mechanical properties of plywood can be done by changing the position of veneer in plywood structure (Jakimovska Popovska and Iliev, 2013), as well as by changing the thickness of the outer layers (Kljak et al., 2006). Research on the in- fluence of composition and number of plywood leayers on panel isotropy was carried on by Lovrić et al. (2015). By combining veneers of different thickness, plywood with adequate characteristics for the intended application can be obtained (Hráskỳ and Král, 2006).

The research of the characteristics of plywood properties in different directions is important for the proper application of these materials as load-bearing panels in different structures in construction (Jakimovska Popovska, 2011).

Previous research has shown that the veneer layouts in plywood structure have a significant impact on plywood bending properties (Jakimovska Popovska and Iliev, 2015). Plywood models, with more veneers in their structure, that run parallel to the span of the loaded panel have higher bending strength and modulus of elasticity in bending (Jakimovska Popovska and Iliev, 2015). The position and orientation of veneers in plywood also have a significant impact on plywood compressive strength (Jakimovska Popovska and Iliev, 2013). Besides these mechanical properties, the tensile strength of plywood is also a property that can define the use of plywood as a structural or non-structural panel.

The aim of the research presented in this paper is to study the impact of veneer layouts on plywood tensile strength, trough the change of the position of veneers in plywood structure around the central axis of the plywood panel, without changing the number and thickness of veneers.

\section{MATERIALS AND METHODS} 2. MATERIJALI I METODE

For the realization of the research, four experimental nine-layer plywood models were made. Each model had the same number of veneers of each thickness class: three veneer sheets with a thickness of 3.2 $\mathrm{mm}$ and two veneer sheets with a thickness of 2.2, 1.5 and $1.2 \mathrm{~mm}$.

The modeling was made on the basis of changing the position of veneers with the thickness of $3.2 \mathrm{~mm}$ around the central axis of the panel. The central layer of each model represents a veneer sheet with the thickness of $3.2 \mathrm{~mm}$, oriented parallel to the face grain of the panel.

In the first model, the veneers with the thickness of $3.2 \mathrm{~mm}$ were positioned next to the central veneer sheet. In the other models, their position moved towards the surface of the panel, so that in the fourth model these veneers built the surface layers of the panel (Figure 1). 

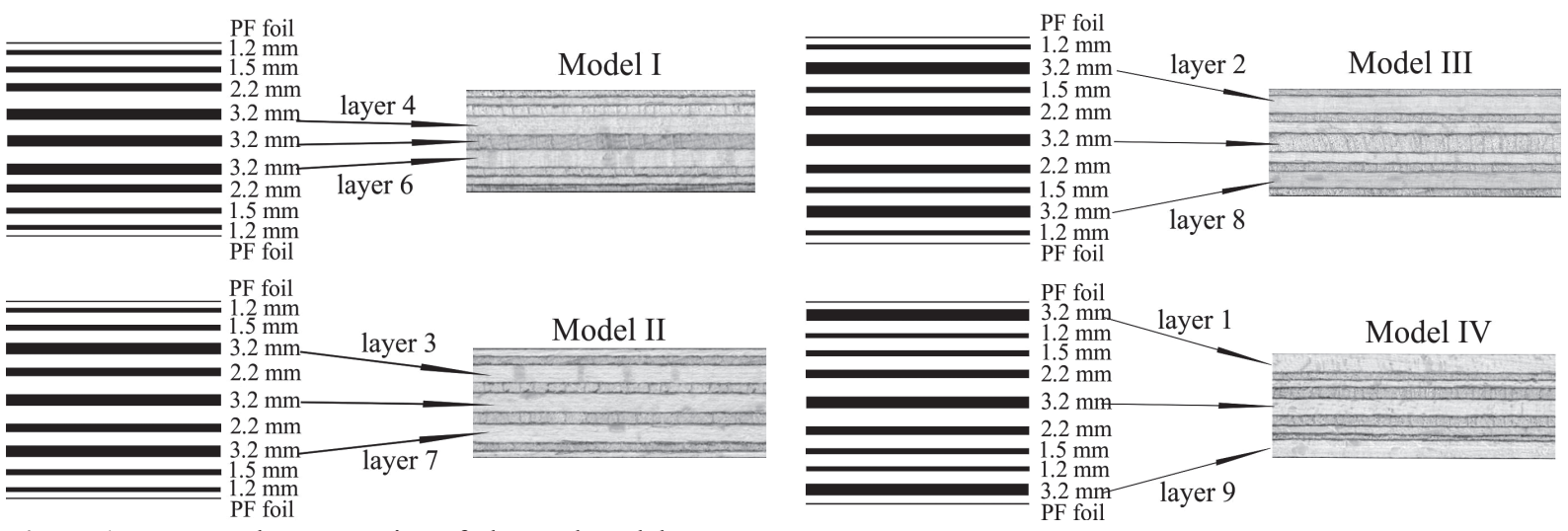

Figure 1 Pattern and cross-section of plywood models

Slika 1. Kompozicija i presjek modela furnirskih ploča

Table 1 Veneer arrangement and orientation in plywood compositions

Tablica 1. Raspored i orijentacija furnira u kompoziciji furnirskih modela

\begin{tabular}{|l|l|}
\hline \multicolumn{2}{|l|}{ Layouts and orientation of veneers in plywood models } \\
Raspored i orijentacija furnira u kompoziciji furnirskih modela
\end{tabular}

The orientation of adjacent layers in plywood structure is at the right angle. In all models, the grain direction of the surface layers is parallel to the longitudinal axis of the panel.

The layots of plywood models and the orientation of the veneers in plywood compositions are described in Table 1.

Pure water-soluble phenol-formaldehyde resin with the concentration of $47.10 \%$ was used as plywood binder, in the quantity of $180 \mathrm{~g} / \mathrm{m}^{2}$.

The panels were pressed in a hot press using the following parameters: specific pressure of $18 \mathrm{~kg} / \mathrm{cm}^{2}$, pressing temperature of $155^{\circ} \mathrm{C}$ and pressing time of 20 $\min$.

The panels were overlaid with phenol formaldehyde-resin impregnated paper with a surface weight of $120 \mathrm{~g} / \mathrm{m}^{2}$. The paper was bonded during the hot pressing process. Plywood overlaying with this paper was made in order to improve the water resistance of plywood, having in mind the fact that these plywood panels were intended for construction purposes, where they can be exposed to high humidity conditions.

The plywood models were made with the following dimensions: $580 \times 580 \times 17 \mathrm{~mm}$. The moisture content of the panels was $8 \%$.

The denotations of the experimental plywood models have the following meaning:

- model I - nine-layer plywood in which the veneers with the thickness of $3.2 \mathrm{~mm}$ are positioned in the fourth, fifth (central) and sixth layer of the panel $\left(d=16.59 \mathrm{~mm} ; \gamma=761.70 \mathrm{~kg} / \mathrm{m}^{3}\right)$;

- model II - nine-layer plywood in which the veneers with the thickness of $3.2 \mathrm{~mm}$ are positioned in the third, fifth (central) and seventh layer of the panel $\left(d=16.77 \mathrm{~mm} ; \gamma=759.99 \mathrm{~kg} / \mathrm{m}^{3}\right)$;
- model III - nine-layer plywood in which the veneers with the thickness of $3.2 \mathrm{~mm}$ are positioned in the second, fifth (central) and eighth layer of the panel $\left(d=16.66 \mathrm{~mm} ; \gamma=782.34 \mathrm{~kg} / \mathrm{m}^{3}\right)$;

- model IV - nine-layer plywood in which the veneers with the thickness of $3.2 \mathrm{~mm}$ are positioned in the surface layers and in the central layer of the panel (first, fifth-central and ninth layer) $(d=16.50 \mathrm{~mm}$; $\left.\gamma=785.90 \mathrm{~kg} / \mathrm{m}^{3}\right)$.

The plywood tensile strength was tested according to the national standard MKC D.A8.066/85. This property was tested in five directions, i.e., parallel and perpendicular to the face grain, and at the angles of $22.5^{\circ} ; 45^{\circ}$ and $67.5^{\circ}$ to the face grain of the panel. The dimensions and shape of the test specimens for the determination of plywood tensile strength are shown in Figure 2.

On the basis of the obtained data for tensile strength in different directions of plywood panel, the coefficient of equality of the tensile strength of plywood models was calculated $\left(K_{e}\right)$. This coefficient was calculated by a graphical method, inputting the values of tensile strength in polar coordinate system (Figure 3 ) and using the equation (Krpan, 1971). A circle with the radius of the highest value of tensile strength was drawn in a polar coordinate system. The area under this circle was calculated. The values of tensile strength in all tested directions were input in the polar system and connected to each other so as to make a diagram with a certain area that was calculated, too. The ratio between the area under the diagram and the area under the circle represent the coefficient of equality of the tensile strength of plywood (Eq. 1).

The curves of the diagram obtained by this kind of tests are symmetrical in all four quadrants of the po- 
a)

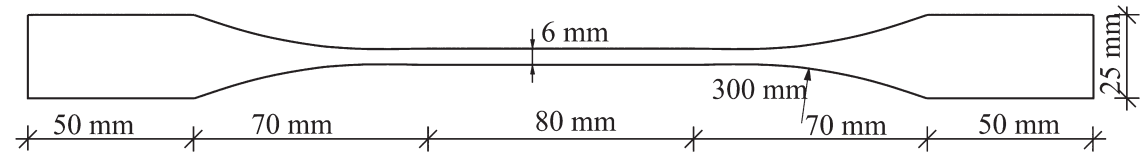

b)

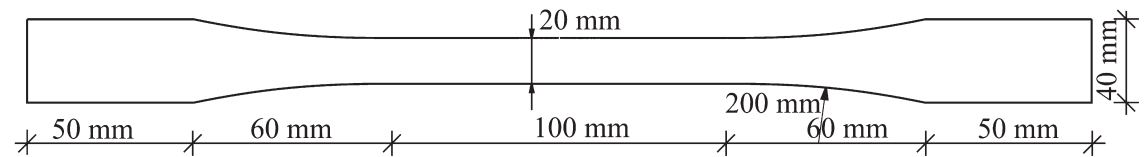

Figure 2 Dimensions and shape of the test specimens for the determination of plywood tensile strength: a) test specimens for the determination of tensile strength parallel and perpendicular to the face grain of plywood; b) test specimens for the determination of tensile strength at different angles to the face grain of plywood

Slika 2. Dimenzije i oblik epruveta za ispitivanje vlačne čvrstoće furnirske ploče: a) epruvete za ispitivanje vlačne čvrstoće paralelno i okomito na smjer vlakanaca vanjskih furnira ploče; b) epruvete za ispitivanje vlačne čvrstoće ploča pri različitim kutovima s obzirom na smjer vlakanaca vanjskih furnira ploče

lar coordinate system, so it is appropriate to test the tensile strength of plywood only in one quadrant and mirror it in the other three quadrants (Krpan, 1971).

$$
K_{e t}=\frac{A_{\mathrm{d}}}{A_{\mathrm{c}}}
$$

Where, $A_{\mathrm{d}}$ - area under the diagram; $A_{\mathrm{c}}$ - area under the circle with the radius of the highest value of tensile strength.

The coefficient of equality of the tensile strength $\left(K_{e t}\right)$ and the coefficient of mass quality $\left(K_{m q}\right)$ define the quality and usability of the plywood panel.

The coefficient of mass quality $\left(K_{m q}\right)$ was calculated by the following equation:

$$
K_{m q}=\frac{\sigma_{t \|+}+\sigma_{t \perp}}{\gamma}
$$

Where, $\sigma_{t \|}$ - tensile strength parallel to the face grain of the plywood panel; $\sigma_{t^{\perp}}-$ tensile strength perpendicular to the face grain of the plywood panel; $\gamma-$ plywood density.

The obtained data were statistically analyzed. One way ANOVA (analysis of variance) was used to determine the significance of the effect of veneer layouts on plywood tensile strength. Shapiro-Wilk test for normality of the obtained data was applied as well as Levene's test for homogeneity of variances. Tukey's test was applied to evaluate the statistical significance between mean values of the tensile strength of plywood with different veneer layouts (different plywood models). The tests were conducted at 0.05 probability level.

Statistical software SPSS Statistic was used for the statistical analysis of the obtained data.

\section{RESULTS AND DISCUSSION 3. REZULTATI I RASPRAVA}

The results of tensile strength in all tested directions of plywood panel are shown in Table 2 .

According to the test results of the tensile strength parallel to the face grain of the panel (Table 2), the following grouping can be done. The values of these properties of models I and III are within similar limits, as well as the values of models II and IV, while the difference in values between the two groups is obvious. The mean value of tensile strength in models II and IV are higher by 32.96 to $62.33 \%$ compared to the mean

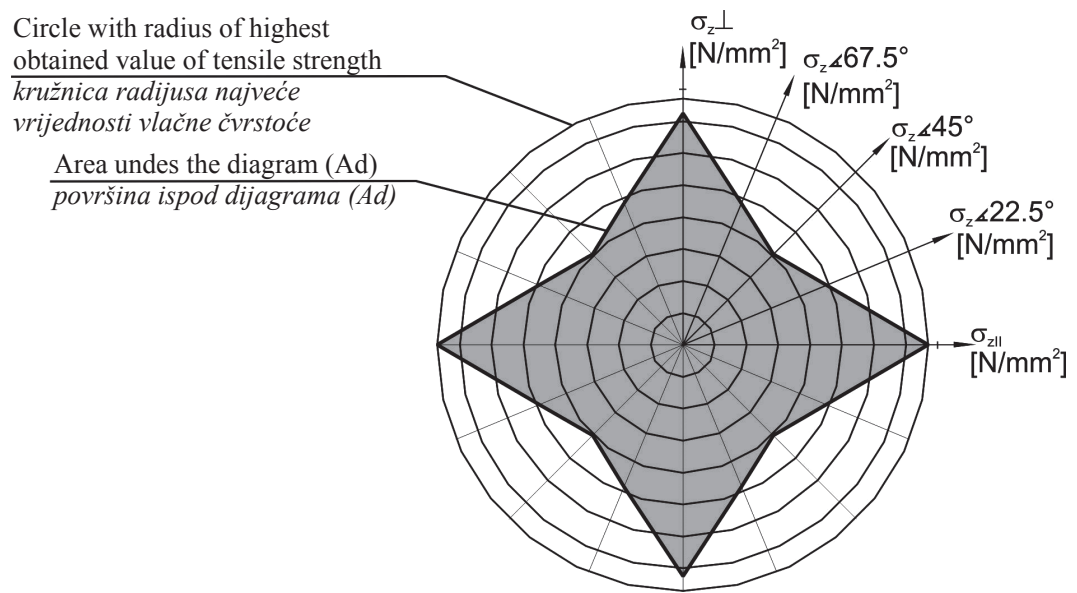

Figure 3 Graphical method for the determination of coefficient of equality of tensile strength of plywood Slika 3. Grafička metoda za određivanje koeficijenta jednakosti vlačne čvrstoće furnirske ploče 
Table 2 Statistical data for tensile strength of plywood in all tested directions

Tablica 2. Statistički podaci o vlačnoj čvrstoći furnirskih ploča u svim istraživanim smjerovima

\begin{tabular}{|c|c|c|c|c|c|c|c|c|c|}
\hline \multirow{2}{*}{$\begin{array}{l}\text { Tensile } \\
\text { strength } \\
\text { Vlačna } \\
\text { čvrstoća }\end{array}$} & \multirow[t]{2}{*}{$\begin{array}{l}\text { Model } \\
\text { Model }\end{array}$} & \multirow[t]{2}{*}{$\begin{array}{c}\text { N } \\
\text { Broj } \\
\text { epruveta }\end{array}$} & \multirow[t]{2}{*}{$\begin{array}{c}\text { Mean } \\
\text { Srednja } \\
\text { vrijednost }\end{array}$} & \multirow{2}{*}{$\begin{array}{l}\text { Std. } \\
\text { Deviation } \\
\text { Standardna } \\
\text { devijacija }\end{array}$} & \multirow{2}{*}{$\begin{array}{l}\text { Std. Error } \\
\text { Greška } \\
\text { srednje } \\
\text { vrijednosti }\end{array}$} & \multicolumn{2}{|c|}{$\begin{array}{l}95 \% \text { Confidence Interval for } \\
\text { Mean } \\
\text { 95-postotni interval pouzdanosti } \\
\text { srednje vrijednosti }\end{array}$} & \multirow[t]{2}{*}{$\begin{array}{l}\text { Min } \\
\text { Min. }\end{array}$} & \multirow[t]{2}{*}{$\begin{array}{l}\text { Max } \\
\text { Maks }\end{array}$} \\
\hline & & & & & & $\begin{array}{l}\text { Lower Bound } \\
\text { Donja granica }\end{array}$ & $\begin{array}{l}\text { Upper Bound } \\
\text { Gornja granica }\end{array}$ & & \\
\hline \multirow{4}{*}{ 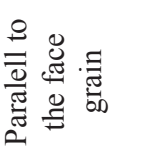 } & I & 5 & $60.55^{\mathrm{a}}$ & 5.57 & 2.49 & 53.63 & 67.47 & 52.92 & 66.29 \\
\hline & II & 5 & $80.51^{\mathrm{b}}$ & 2.74 & 1.23 & 77.11 & 83.91 & 76.32 & 83.50 \\
\hline & III & 5 & $54.10^{\mathrm{a}}$ & 4.08 & 1.83 & 49.04 & 59.17 & 49.36 & 59.55 \\
\hline & IV & 5 & $87.82^{b}$ & 9.01 & 4.03 & 76.64 & 99.00 & 73.40 & 97.65 \\
\hline \multirow{4}{*}{ 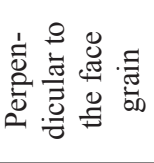 } & I & 5 & $73.17^{\mathrm{a}}$ & 6.65 & 2.97 & 64.91 & 81.43 & 66.59 & 81.43 \\
\hline & II & 5 & $57.73^{\mathrm{b}}$ & 1.97 & 0.88 & 55.28 & 60.17 & 54.96 & 60.44 \\
\hline & III & 5 & $74.63^{\mathrm{a}}$ & 8.03 & 3.59 & 64.66 & 84.60 & 63.53 & 84.11 \\
\hline & IV & 5 & $46.98^{\mathrm{c}}$ & 5.08 & 2.27 & 40.67 & 53.28 & 39.18 & 52.26 \\
\hline \multirow{4}{*}{ 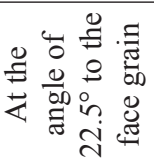 } & $\mathrm{I}$ & 5 & $34.16^{\mathrm{a}}$ & 2.32 & 1.04 & 31.28 & 37.04 & 31.54 & 36.86 \\
\hline & II & 5 & $35.38^{\mathrm{a}}$ & 1.01 & 0.45 & 34.13 & 36.64 & 34.21 & 36.64 \\
\hline & III & 5 & $36.53^{\mathrm{a}}$ & 2.39 & 1.07 & 33.56 & 39.50 & 33.92 & 38.78 \\
\hline & IV & 5 & $33.69^{\mathrm{a}}$ & 2.61 & 1.17 & 30.45 & 36.93 & 29.76 & 36.37 \\
\hline \multirow{4}{*}{ 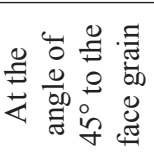 } & I & 5 & $27.18^{\mathrm{a}, \mathrm{b}}$ & 1.39 & 0.62 & 25.45 & 28.90 & 25.58 & 28.93 \\
\hline & II & 5 & $25.90^{\mathrm{a}}$ & 1.28 & 0.57 & 24.31 & 27.49 & 24.67 & 27.51 \\
\hline & III & 5 & $27.49^{\mathrm{a}, \mathrm{b}}$ & 0.42 & 0.19 & 26.97 & 28.01 & 26.93 & 27.97 \\
\hline & IV & 5 & $27.97^{\mathrm{b}}$ & 0.99 & 0.44 & 26.74 & 29.20 & 27.06 & 29.45 \\
\hline \multirow{4}{*}{ 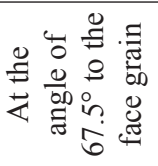 } & $\mathrm{I}$ & 5 & $35.47^{\mathrm{a}}$ & 2.08 & 0.93 & 32.89 & 38.05 & 33.66 & 37.86 \\
\hline & II & 5 & $36.04^{\mathrm{a}}$ & 0.97 & 0.43 & 34.83 & 37.24 & 35.01 & 37.09 \\
\hline & III & 5 & $35.96^{\mathrm{a}}$ & 2.47 & 1.10 & 32.90 & 39.03 & 32.85 & 39.26 \\
\hline & IV & 5 & $28.50^{\mathrm{b}}$ & 2.25 & 1.00 & 25.71 & 31.29 & 26.34 & 31.98 \\
\hline
\end{tabular}

Note: The mean values marked with the same letters are not significantly different at 0.05 probability level.

Napomena: Srednje vrijednosti označene istim slovom nisu signifikantno različite pri razini signifikantnosti 0,05.

value in models I and III. The highest value of tensile strength parallel to the face grain of the panel is achieved in model IV.

The analysis of variance of data obtained for tensile strength parallel to the face grain (ANOVA: $F$ (3, 16) $=37.551 ; p=0.000)$ showed that the differences between the mean values of these properties of (at least) two plywood models are statistically significant. The conducted post-hoc Tukey's test for multiple comparison between models showed that there are statistically significant differences in the mean values of this property of models I and III compared to models II and IV. The difference in the values of tensile strength parallel to the face grain between the two groups of models results from the orientation of the veneers in the plywood structure, particularly of the veneers with the thickness of $3.2 \mathrm{~mm}$, as they account for the highest percentage of the panel thickness. In models I and III, two of the three veneer sheets with the thickness of 3.2 $\mathrm{mm}$ are oriented perpendicular to the length of the test specimen (perpendicular to the direction of tensile force), while in models II and IV all three veneers with the thickness of $3.2 \mathrm{~mm}$ are oriented parallel to the direction of tension load. The reason for the higher values of tensile strength parallel to the face grain in models II and IV compared to models I and III lies in a higher number of longitudinally oriented veneers with the thickness of $3.2 \mathrm{~mm}$. In models II and IV, the veneers oriented parallel to the direction of tensile force account for a higher percentage of panel thickness.
Having in mind the fact that the total number of veneers, oriented in the same direction, has the main influence on tensile strength, it is clear why this property is higher in models II and IV. In fact, the highest thickness ratio of the veneers that run parallel to the panel length (the veneers that run parallel to the panel length account for $64.9 \%$ of panel thickness) is found in model IV, and this contributes in the acchievemnt of the highest value of tensile strength parallel to the face grain of the panel. In model II, the veneers that run parallel to the direction of tensile force account for $61.9 \%$ of panel thickness. In models I and III veneers that run parallel to the direction of tensile force account for $48.5 \%$ and $44.3 \%$ of the plywood nominal thickness, respectively.

The differences in the mean values of tensile strength between model I and model III, as well as between model II and model IV, are small and they are not statistically significant.

According to the results of tensile strength perpendicular to the face grain of plywood (Table 2), models I and III have higher values of tensile strength in cross-grain direction compared to the models II and IV. The highest value of this property is achieved in model III, which is higher for $29.27 \%$ compared to model II and for $58.85 \%$ compared to model IV. The analysis of variance of the obtained data (ANOVA: $F(3,16)=$ 25.223; $p=0.000$ ) and post-hoc Tukey's test showed that these differences are statistically significant. Models I and III have similar values of tensile strength in 
cross-grain direction, whereas the differences between them are not statistically significant. The lowest value of this property is achieved in model IV and this value statistically differs from the values of all other plywood models.

The differences in the values of tensile strength in cross-grain direction in different models are also a result of the orientation of the veneers with thickness of $3.2 \mathrm{~mm}$ in plywood structure. The highest values of tensile strength perpendicular to the face grain of the panel are achieved in models that have more veneers with thickness of $3.2 \mathrm{~mm}$ running parallel to the direction of tensile loading (model I and III). Models II and IV have all three veneers with thickness of $3.2 \mathrm{~mm}$ running perpendicular to the tensile force. In fact, the higher values of tensile strength in cross-grain direction are achievd in models that have higher thickness ratio of the veeers that run parallel to the tensile force (model I and III which have $48.5 \%$ and $44.3 \%$ of panel thickness occupied by the veneers that run parallel to the direction of tensile force, compared to models II and IV which have $38.1 \%$ and $35.1 \%$ of panel thickness occupied by the veneers that run parallel to the direction of tensile force).

The lowest value of this property that is achieved in model IV, shows that positioning the veneers with thickness of $3.2 \mathrm{~mm}$ as surface layers of the panel, has a negative effect on the value of tensile strength in cross-grain direction of the panel.

The results for the tensile strength at the angle of $22.5^{\circ}$ to the face grain of plywood are also shown in Table 2, where can be seen that all plywood models have similar values of this property. The analysis of variance of the obtained data (ANOVA: $F(3,16)=$ $1.727 ; p=0.202$ ) showed that there is no statistically significant differences in the mean values between all plywood models, which means that the orientation and position of the veneers with thickness of $3.2 \mathrm{~mm}$ has no significant impact on the tensile strength when the panels are stressed in tension at the angle of $22.5^{\circ}$ to the face grain of plywood.

When plywood panels are exposed on tension at the angle of $45^{\circ}$ to the face grain there are statistically significant differences in the mean values of tensile strength between plywood models (ANOVA: $F(3,16)$ $=3.305 ; p=0.047)$. The post-hoc Tukey's test showed that there is a statistically significant difference in the mean values only between model II and model IV. The highest value of tensile strength in this direction of the panel is achieved in model IV, with notation that all plywood models have similar values of this property. The maen value of model IV is higher compared to the mean values of model I, II and III for $2.91 \%, 8 \%$ and $1.75 \%$, respectively.

In case when plywood panels are stressed in tension at the angle of $67.5^{\circ}$ to the face grain of the panel, the highest value of tensile strength is achieved in model II, which value is higher for $26.46 \%$ compared to model IV, which have the lowest obtained value of tensile strength in this direction of the panel. The analysis of variance of the obtained data (ANOVA: $F$ (3,
16) $=16.405 ; p=0.000)$ and the post-hoc Tukey's test showed that there are statistically significant differences in the mean values between model IV and all other plywood models. The differences between models I, II and III are very small and they are not statistically significant.

The national standard MKC D.C5.043 for loadbearing plywood for use in construction defines the minimal values of tensile strength of $24 \mathrm{~N} / \mathrm{mm}^{2}$ parallel to the face grain; $12 \mathrm{~N} / \mathrm{mm}^{2}$ perpendicular to the face grain and $6 \mathrm{~N} / \mathrm{mm}^{2}$ at the angles of 30 and $60^{\circ}$ to the face grain of the plywood panel. According to this standard the values of tensile strength in other directions of plywood can be obtained by linear interpolation by the given values for tensile strength parallel, perpendicular and at the angle of $30^{\circ}$ and $60^{\circ}$ to the face grain of the plywood panel. The obtained minimal value by the linear interpolation for tensile strength at the angle of $22.5^{\circ}$ to the face grain is $10.5 \mathrm{~N} / \mathrm{mm}^{2}$ and at the angle of $67.5^{\circ}$ is $7.5 \mathrm{~N} / \mathrm{mm}^{2}$. All experimental plywood models exceed the minimal values defined bay the standard in all tested directions of the panel.

The obtained values of plywood tensile strength are within the limits of the values for this property listed in available literature. Nikolić (1988) for five-layer beech plywood gives the values of $71.1 \mathrm{~N} / \mathrm{mm}^{2}$ for tensile strength parallel to the face grain of the panel, 62.5 $\mathrm{N} / \mathrm{mm}^{2}$ for tensile strength perpendicular to the face grain and $22.2 \mathrm{~N} / \mathrm{mm}^{2}$ for tensile strength at the angle of $45^{\circ}$ to the face grain of the plywood panel. Brezovic et al. (2002) give the values of 49.12 and $28.63 \mathrm{~N} / \mathrm{mm}^{2}$ for tensile strength parallel and perpendicular to the face grain of poplar plywood. Arriga and Peraza (2004) for pine plywood with thickness of 15 and $18 \mathrm{~mm}$ give the values of 22.3 and $19.5 \mathrm{~N} / \mathrm{mm}^{2}$ for tensile strength parallel to the face grain and the values of 15.0 and $17.5 \mathrm{~N} / \mathrm{mm}^{2}$ for tensile strength perpendicular to the face grain of the panel. Kljak and Brezovic (2007a) give the values of $53.5 \mathrm{~N} / \mathrm{mm}^{2}$ and $59.2 \mathrm{~N} / \mathrm{mm}^{2}$ for tensile strength parallel and perpendicular to the face grain of seven-layer beech plywood with thickness of $10.52 \mathrm{~mm}$.

On the basis of the polar diagrams of tensile strength showed on Figure 4 it can be noticed that models I and III, as well as models II and IV have similar tendency of increment or decrement of tensile strength in relation to the direction of tensile force regarding the orientation of the wood fibers of the surface veneers.

In models I and III, the highest value of tensile strength is achieved in direction perpendicular to the face grain of plywood, while in models II and IV the highest value of tensile strength is achieved in direction parallel to the face grain of the panel. The lowest value of tensile strength in all plywood models is achieved in direction at the angle of $45^{\circ}$ to the face grain of plywood. At the angles of $22.5^{\circ}$ and $67.5^{\circ}$, the values of tensile strength are higher compared to the value of tensile strength at the angle of $45^{\circ}$, but lower compared to the values of tensile strength parallel and perpendicular to the face grain of plywood. With the 


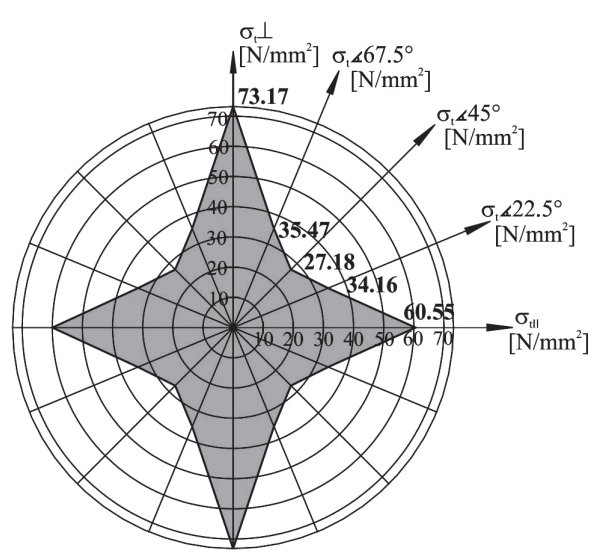

Model I

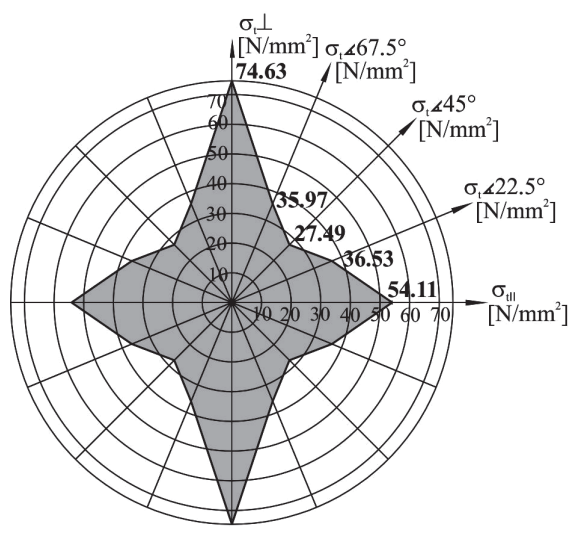

Model III

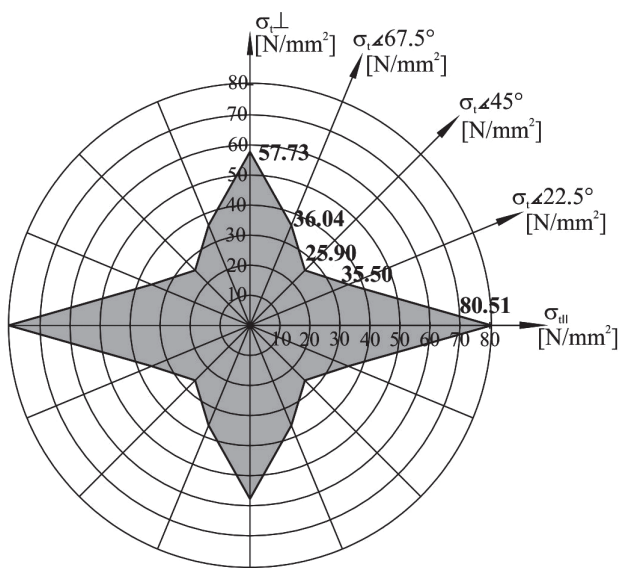

Model II

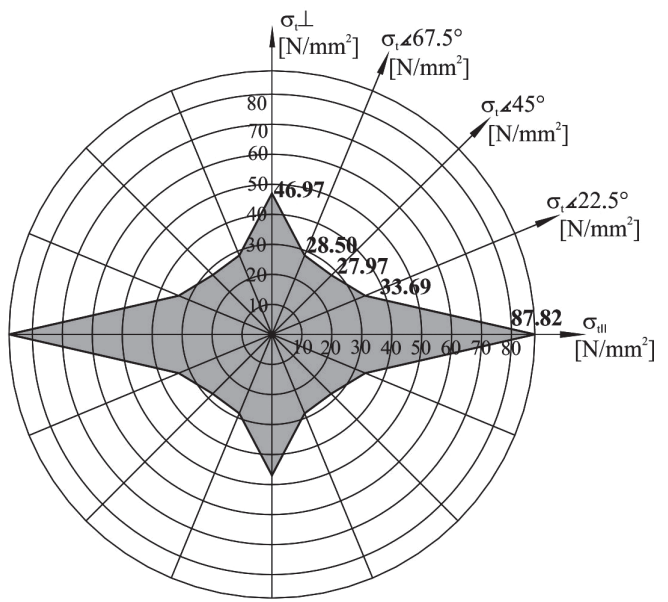

Model IV

Figure 4 Polar diagrams of plywood tensile strength

Slika 4. Polarni dijagrami vlačne čvrstoće furnirskih ploča

exception of model IV, the values of tensile strength at the angels of $22.5^{\circ}$ and $67.5^{\circ}$ are similar to each other.

The differences in the values of tensile strength in different directions of plywood panel are a result of the orientation of wood fibers in plywood structure in relation to the direction of the action of tensile force. This means that the orientation of veneers in plywood structure has direct impact on plywood tensile strength.

The tensile strength of wood is higher in the direction of the wood fibers. By increasing the angle between the wood fibers and the direction of the tensile force, the tensile strength of wood is decreasing. At the angles between $60^{\circ}$ and $90^{\circ}$, the tensile strength of wood is almost equal to the tensile strength perpendicular to the wood fibers (Lukić-Simonović, 1983).

The veneers with the thickness of $3.2 \mathrm{~mm}$ in experimental plywood account for the highest thickness percentage of the plywood panel, so the value of tensile strength depends on its orientation to the direction of the tensile force. The orientation of these veneer sheets in models II and IV is parallel to the face grain of the panel, which results in the highest value of the tensile strength in this direction of the plywood panel. In fact, the higher values of tensile strength parallel to the face grain are achievd in models that have higher thickness ratio of the veneers that run parallel to the tensile force. For the same reason, model I and III have higher values of ten- sile strength when the panels are stressed in tension perpendicular to the face grain of the panels. In this case, all three veneers with the thickness of $3.2 \mathrm{~mm}$ are oriented parallel to the direction of tensile force.

The values of the coefficients of equality of tensile strength (Table 3 ) calculated on the basis of the polar diagrams showed that differences in tensile strength in different directions of plywood panel are smaller in models I and III compared to models II and IV. The lowest coefficient is obtained in model IV, which means that the highest differences in tensile strength in different panel directions appear in this plywood model.

The coefficients of mass quality of plywood panels (Table 3) represent the tensile strength to weight ratio of plywood models. From the value of the coefficient of mass quality, the values of the material properties in relation to its density can be seen. The values of this coefficient show that the highest tensile strength to weigth ratio is determined in model II compared to other plywood models. The increment of the value of this coefficient speaks for a higher quality of plywood structure. For comparison, the coefficient of steel mass quality is 1026 (Nikolić, 1988).

The failure mode of the test specimens for the determination of the tensile strength is shown in Figure 5. The visual analysis of test specimens, during testing 


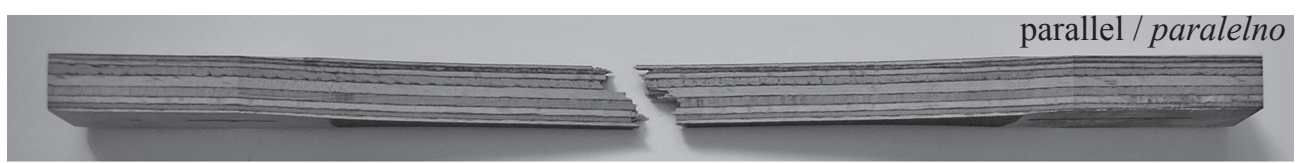

parpendicular / okomito

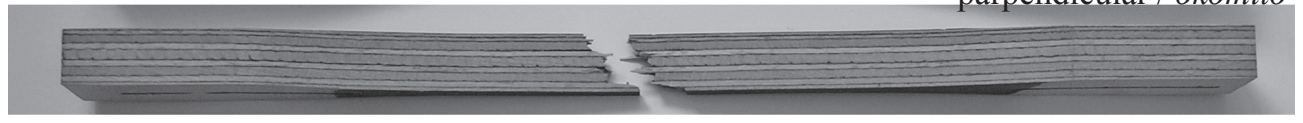

angle $20.5^{\circ} / k u t 22,5^{\circ}$

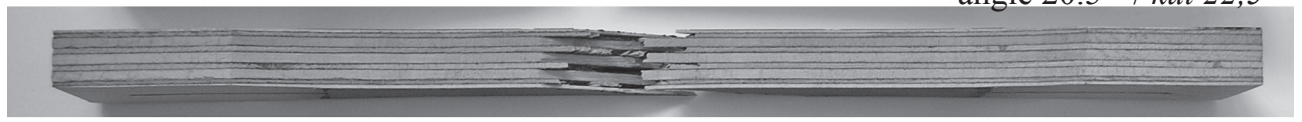

angle $45^{\circ} / \mathrm{kut} 45^{\circ}$

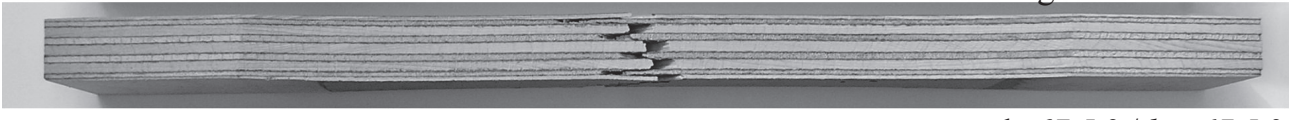

angle $67.5^{\circ} /$ kut $67,5^{\circ}$

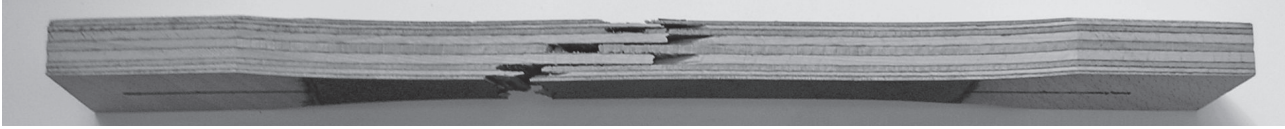

Figure 5 Faliure modes of test specimens for the determination of tensile strength

Sika 5. Načini loma ispitivanih uzoraka za određivanje vlačne čvrstoće

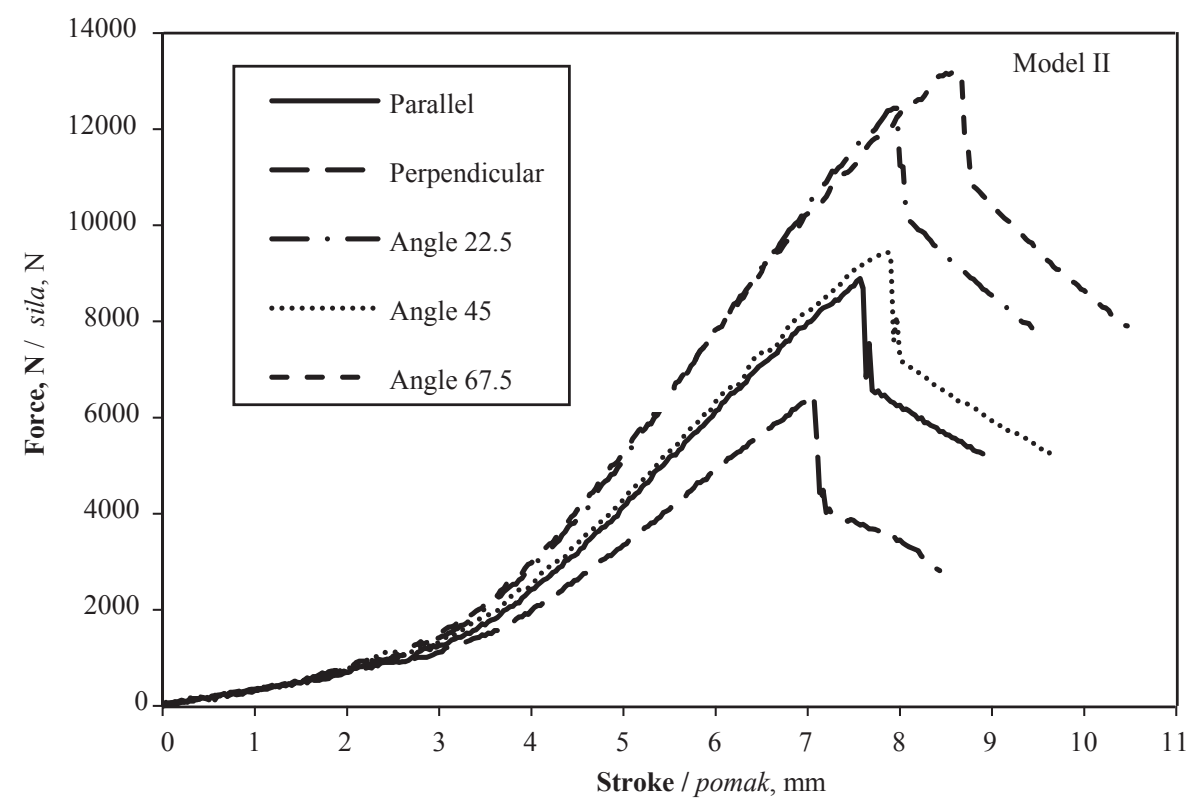

Figure 6 Force-stroke diagram during testing the tensile strength of representative plywood model

Slika 6. Dijagram sila - pomak pri ispitivanje vlačne čvrstoće reprezentativnog modela furnirske ploče

Table 3 Coefficients of equality of tensile strength $\left(K_{e t}\right)$ and coefficients of mass quality $\left(K_{m q}\right)$ of plywood

Tablica 3. Koeficijenti jednakosti vlačne čvrstoće $\left(K_{e t}\right)$ i

koeficijenti masene kvalitete $\left(K_{m q}\right)$ furnirskih ploča

\begin{tabular}{|c|c|c|}
\hline Model / Model & $\boldsymbol{K}_{\text {et }}$ & $\boldsymbol{K}_{\mathbf{m q}}$ \\
\hline I & 0.30 & 1790 \\
\hline II & 0.26 & 1855 \\
\hline III & 0.29 & 1678 \\
\hline IV & 0.19 & 1749 \\
\hline
\end{tabular}

of tensile strength, showed that the failure of the test specimens occurred at once, whitout prior delamination of veneers.

The force-stroke diagrams, during testing of tensile strength (Figure 6), showed that the failure of the material occurred at once without significant plastic deformation.

\section{CONCLUSION 4. ZAKLJUČAK}

On the basis of the research, it can be concluded that different veneer layouts in plywood structure have significant impact on plywood tensile strength. The difference in the values of tensile strength between different plywood models results from the orientation of the veneers in the plywood structure, particularly of the veneers with a thickness of $3.2 \mathrm{~mm}$, as they account for the highest thickness percentage of the panel.

The highest values of tensile strength are achieved in plywood models in which the veneers with 
the thickness of $3.2 \mathrm{~mm}$ are oriented parallel to the direction of tensile force. Therefore, the recommendation is to use the configuration of models II and IV in cases when the panels are loaded in tension parallel to the face grain of the panel.

When the panels are loaded in tension in cross grain direction, or when a greater equality of the values of tensile strength in different directions of the panel is required, then the configurations of models I and III are recommended.

The production of plywood with different veneer layouts in panel structure gives opportunities for production of panels that can meet different application requirements. Trough the change of the veneer position in plywood structure, without changing the number and thickness of veneers, plywood panels with different strength characteristics can be designed. Therefore, the choice of a certain plywood configuration will depends on the application area, i.e., the type of loads to which the panel is exposed during its use.

\section{REFERENCES}

\section{LITERATURA}

1. Arriga, F.; Pereza, F., 2004: Characteristic values of mechanical properties of radiata pine plywood, http://www.ewpa.com/Archive/2004/jun/Paper 314.pdf.

2. Brezović, M.; Jambreković, V.; Kljak, J., 2002: Utecaj karbonskih vlakana na neka relevantna svojstva furnirskih ploča. Drvna industrija, 53(1): 23-31.

3. Bal, B. C.; Bektaş, İ., 2014: Some mechanical properties of plywood produced from eucalyptus, beech and poplar veneers. Maderas Cienc. Tecnol, 16(1): 99-108. https://doi.org/10.4067/s0718-221x2014005000009.

4. Cai, Z.; Ross, R. J., 2010: Mechanical properties of wood-based composite materials, Chapter 12 in Wood handbook - Wood as engineering material. USDA, FPL, General Technical Report-190: 12-1 - 12-12.

5. Hrázský, J.; Král, P., 2005: Assessing the bending strength and modulus of elasticity in bending of exterior foiled plywoods in relation to their construction. J For Sci, 51(2): 77-94.

6. Hrázský, J.; Král, P., 2006: Effects of the Thickness of Rotary-Cut Veneers on Properties of Plywood Sheets. Part 2. Physical and Mechanical Properties of Plywood Materials. J For Sci, 52(3): 118-129.

7. Jakimovska Popovska, V., 2011: Comparative researches of the properties of laboratory plywood and some industrial manufactured wood-based panels. Master thesis, „SS.Cyril and Methodius“ University in Skopje (in Macedonian).

8. Jakimovska Popovska, V.; Iliev, B., 2013: Ifluence of plywood structure on compressive strength parallel to the plane of the panel, Proceedings of $1^{\text {th }}$ International Scientific Conference „Wood Technology \& Product Design”, 16-18 May 2013, Ohrid, pp. 194-200.

9. Kljak, J.; Brezović, M.; Jambreković, V., 2006: Plywood stress optimization using the finite element method. Wood Research, 51(1): 1-10.
10. Kljak, J.; Brezovic, M., 2007: Relationship between bending and tensile stress distribution in veneer plywood. Forest Products Journal, 57(12): 65.

11. Kljak, J.; Brezović, M., 2007a: Effect of shear components on stress values in plywood panel subjected to tensile load. Drvna industrija, 58(3): 135-139.

12. Krpan, J., 1970: Tehnologija furnira i ploča. Zagreb: Tehnička knjiga.

13. Lukić-Simonović, N., 1983: Poznavanje svojstava drveta (autorska skripta). Beograd.

14. Lovrić, A.; Zdravković, V.; Lovanović, L., 2015: Influence of composition and number of layers of poplar plywood (populous euramericana) on bending strength and modulus of elasticity. Proceedings of $2^{\text {nd }}$ International Scientific Conference „Wood Technology \& Product Design", 2015, Ohrid, pp. 1-7.

15. Nikolić, M., 1988: Furnirne i slojevite ploče. Beograd: Građevinska knjiga.

16. Stark, N. M.; Cai, Z.; Carll, C., 2010: Wood handbookWood as engineering material, Chapter 11: Wood-based composite materials. USDA, Forest Product Laboratory, General Technical Report, 190: 11-28.

17. Youngquist, J. A., 1999: Wood-based composites and panel products. Chapter 10 in USDA, Forest Service, Wood as an engineering material. General Technical report FPL-GTR-113. Wood Handbook. USDA, Forest Service, Forest Products Laboratory.

18. ***MKC D.A8.066 - 1985: Ispituvanje na sloeviti proizvodi od drvo. Furnirski plochi. Opredeluvanje na jakost na zategnuvanje i modul na elastichnost. Makedonski standardi.

19. ***MKC D.C5.043 - 1982: Furnirski plochi za nosivi drveni inzhenerski konstrukcii vo gradezhnishtvoto. Makedonski standardi.

20. ${ }^{* * *}$ 1957: Symposium on tension testing of non-metallic materials: presented at the fifty-ninth annual meeting, American Society for Testing Materials, Atlantic City, N. J., June 20, 1956. Philadelphia, Pa.: American Society for Testing and Materials. Special Technical Publication No. 194: 64 .

21. ***2009: Structural plywood \& LVL design manual, EWPAA-Engineered Wood Products Association of Australasia. http://www.ewp.asn.au (Accessed March 25, 2010).

\section{Corresponding address:}

Assist. Prof. VIOLETA JAKIMOVSKA

POPOVSKA, Ph. D.

Department of Wood Composite Materials

Faculty of Design and Technologies of Furniture and Interior

University of SS. Cyril and Methodius in Skopje

P.O. Box 8

1130 Skopje, REPUBLIC OF MACEDONIA

e-mail: jakimovska@fdtme.ukim.edu.mk 